УДК 327 (73)

\title{
ПРЕЗИДЕНТ vs ГРОМАДЯНСЬКЕ СУСПІЛЬСТВО: ДО ПИТАННЯ ПРО РЕАЛІЗАЦІЮ ПОЛІТИЧНОЇ ВЛАДИ США
}

\section{Дудко Ірина}

Розглядаються теоретичні і практичні виміри реалізації політичної влади на прикладі президениіоналізму США. Ідеєю дискурсу є з'ясування, щз зумовлює орієнтованість президентів США на загальнонаціональні інтереси попри елітарний статус осіб, щчо посідають президентський пост. У колі уваги - традиційно високі вимоги американських громадян щзодо моральних та ділових якостей президента, здатність обраного лідера відповідати на запити та потреби суспільства. Вагомої ролі в аспекті загальнонаціональних позицій влади набувають й інституційні засади, насамперед, нагляд і контроль за діяльністю президента і президентської адміністрації з боку конгресу США, щзо - на прикладі активності представлених в конгресі груп інтересу (тиску), формальних і неформальних об'єднань, виступів впливових політичних індивідуальностей - виявив здатність функціонувати в ролі контрактора виконавчої влади, реалізуючи таким чином практичну дієвість принципу стримування і противаг. Серед механізмів впливу на президента й низка соиіальних чинників, особливу роль серед яких посідають ЗМI і громадська думка. В статті доводиться, щуо попри спроможність виконавчої влади впливати на формування у необхідному для неї напрямі громадської думки, остання (в умовах дієвості інституиійного чинника - конгресу) стає виразником інтересів, позицій, запитів громадян. Значна роль в цььому плані належить й засобам масової інформачії, щуо залишаються важливим регулятором політичних зв'язків між суспільством і урядовими структурами, залишаючись значною мірою самостійною силою щзодо офіційних владних впливів. Таку ж роль виконує й судова система США як додатковий правовий інструмент підтримки демократії $і$ захисту позииї громадян за умов конфліктності інтересів по лінії громадянисуспільство - конгрес - президент.

У статті доводиться, щуо реалізація влади в інтересах суспільства передбачає як особливі якості претендентів на вищі керівні посади, так і наявність сталих демократичних норм, щуо регулюють діяльність керівника начії у вимірах інтересів та потреб громадян.

Ключові слова: влада, президенціоналізм США, теорія, практика, національні інтереси.

Президентські і парламентські вибори 2019 р. проходили під гаслом «повного перезавантаження влади» як передумови, з погляду новобраної політичної еліти, оновлення владних структур, очищення керівництва від негативів попередніх років, пов'язаних, зокрема, з корупцією, злиттям влади і бізнесу, олігархічними інтересами політичної еліти в реалізації внутрішньо- і зовнішньополітичного курсу держави. Серед викликів демократії-й відчуження влади від суспільства як тенденції, що зумовлювалася як вузькістю інтересів політичної еліти (що висувала за мету діяльності переважно соціально обмежені, а не суспільні інтереси), так і особливий соціальний статус представників влади, що відокремлював керівництво від пересічних громадян.

Утім, питанням залишається, наскільки повне перезавантаження влади як обрання до владних структур осіб, не пов'язаних попередньо з олігархічним i 
владними колами, є гарантією забезпечення прагматично й соціально орієнтованого керівництва державою і що зумовлює водночас еліту сталих демократій діяти в інтересах нації, попри непересічний соціальний та політичний статус осіб, які посідають вищі державні посади? Презіденціоналізм США заслуговує в цьому відношенні на особливу увагу з урахуванням безпрецедентних політичних повноважень, яких набувають особи, що обираються на посаду президента Сполучених Штатів, та їхня приналежність до прошарків, що формують традиційно соціальну еліту США. Формування уявлень про американський президенціоналізм у вимірі реалізації політичної влади набуває, таким чином, особливе значення; може мати практичний аспект з урахуванням потреб вдосконалення подальшого державно-політичного керівництва нових демократій, включно 3 Україною.

Варто визнати, що президенціоналізм США у вимірі реалізації політичного керівництва є об'єктом наукового осмислення значного кола американських авторів, серед яких Ф. Гартманн. О. Джордж, С. Кернелл, С. Крабб, Н. Левін, Б. Мірофф, Р. Ньюстадт, Дж. Розаті, Р. Хілсман, А. Шлезінгер, Р. Шпітсер та інші, що сформували фундаментальну дослідницьку основу для комплексного сприйняття проблеми реалізації політичної влади з погляду на політичний і соціальний статус першої особи країни. Певний внесок в розробку теми здійснили українські вчені, враховуючи напрацювання зарубіжних і вітчизняних дослідників [9]. Втім, проблему не можна вважати абсолютно вичерпаною з урахування нових явищ американського президенціоналізму («феномен Трампа»), а також реалізації президентських функцій за новітніх обставин функціонування політичної системи США.

Метою статті $є$ визначення основоположних підходів до сприйняття президенціоналізму як прояву загальнонаціонального лідерства США; окреслення механізмів забезпечення діяльності американських президентів у напрямі, що відповідає потребам та інтересам американського суспільства

Так, варто визнати, насамперед, що обрання 2016 р. на пост президента США від Республіканської партії США Д. Трампа належить до подій неординарного характеру в історії країни - як з урахуванням результатів виборів, так і персональних якостей особи, обраної на президентську посаду. Незважаючи на те, що за головну суперницю Д. Трампа від Демократів на виборах - Г. Клінтон - проголосували 64,2 млн, тоді як за Трампа 62,2 млн американців, останній здобуває перемогу завдяки суттєвій перевазі голосів вибірників: 306 за Трампа після підрахунку голосів в усіх штатах проти 232 голосів за Клінтон (другий в історії США новітніх часів випадок після протистояння Дж. Буша-молодшого i А. Гора у виборах 2000 р.). 
Трамп здобуває перемогу попри контроверсійність його особи, що не мав відповідного державно-політичного досвіду та й до того неодноразово протягом передвиборчої кампанії опинявся в епіцентрі скандалів, зокрема, через сумнівність висловлювань щодо жінок, мусульман та мігрантів. Кілька жінок звинуватили його в сексуальних домаганнях. Втім, Трампа як неординарну особистість, що декларував зміни, підтримувала значна частина американців, і саме це, поряд із новітніми політтехнологіями, які активно використовувалися командою Трампа, визначило результат виборів, які відбулись в листопаді 2016 р. [13, 358-359].

Розглядаючи феномен Трампа, аналітики акцентують, зокрема, та такій виправданій технології передвиборчої кампанії президента, як безпосередні звернення до пересічних громадян США. Так, заяви на кшталт інавгураційної промови Трампа - «Ми, громадяни Америки, цієї миті об’єднали свої спільні зусилля у великій національній справі відновлення нашої країни і здійснення своїх обіцянок перед всім американським народом...» [5] - знаходили відгук на тлі помітного відчуження американської політичної еліти від пересічних громадян та небажання останніх миритися з цим фактом. Зокрема, за даними впливового британського журналу «Економіст», за період 2002-2015 рр. кількість американців, які вважали, що в їхній країні влада належить народу, зменшилася майже вдвічі - 344 \% до 23 \%. Виявилося, що внаслідок широко розрекламованої глобалізації, розвитку вільної торгівлі, зняття бар'єрів для інвестицій тощо збагачувався лише незначний прошарок американців, а решта - втрачали роботу, звичний стиль життя та рівень добробуту і, як наслідок, - впевненість у майбутньому. Відсутність виразної реакції американського істеблішменту на ці тенденції стало наочним підтвердженням і відчуження, і розчарування. Останнє доволі чітко виявилося у даних своєрідного анти-рейтингу Гілларі Клінтон, - близько 55 \% американців сприймали іiі негативно [10].

Отже, стратегія на загальнонаціональні інтереси (інтереси громадян) та спроможність діяти у вимірі цієї стратегії сприймається в американському суспільстві як одна з важливіших, втім, не єдиної вимоги щодо персони президента країни. Не менш вагомим є моральне обличчя політика, що набуває статусу представника нації. Показово, що перманентні звинувачення Трампа в нехтуванні моральними нормами вже після обрання останнього на посаду президента стали передумовою надзвичайно низького рівня підтримки чинного глави держави 3 боку американців, попри протекціонізм у внутрішній політиці як прагнення «повернути американцям робочі місця» [5] або змоги протистояння зовнішнім викликам (ядерна програма КНДР, Ірану). Рейтинг схвалення політики Дональда Трампа після 21 місяця роботи виявився нижчим, ніж у Барака Обами, Джорджа Буша та Біла Клінтона після проходження аналогічного терміну. Якщо відразу 
після інавгурації рейтинг схвалення політики Дональда Трампа становив 45,5 \%, то трохи більше року потому, після численних звинувачень у сексуальних домаганнях, протистояння зі ЗМІ, боротьби з ФБР (особливо у справі зв'язків команди Трампа з Кремлем на етапі передвиборчої кампанії), позначка впала до 34,6 \%. Наразі, у вересні 2018 р., за 6 тижнів до проміжних виборів до Конгресу США, рейтинг чинного президента США становив 41,4\%. Для порівняння, рейтинг схвалення політики Барака Обами відразу після інавгурації досягав 68 \%, а після перших 21 місяців роботи - 45,3\% [18].

Рейтингові показники щодо підтримки Д. Трампа - опосередковане підтвердження високого рівня критеріальних вимог, які висуваються громадянами до особи президента, що, будучи обраним на вищу державну посаду, має представляти суспільство і виступати від імені суспільства. Втім, як показує практика, система виборів, навіть в країні сталої демократії, якими є США, не гарантує відповідно до реалій обрання на вищу державну посаду найбільш достойних кандидатів, що об'єктивно окреслює проблему надзвичайних повноважень глави держави та ступеня спрямування цих повноважень на реалізацію суспільних інтересів.

Загалом проблема повноважень президента активно обговорюється в сучасній політичній літературі як у вимірі основоположних засад американської демократії, так і тих інтересів, які впливають на позиції глави держави. Поширеною 3 погляду теоретичного осмислення проблеми повноважень президента є та позиція, що особливий (окреслений надзвичайними владними функціями) статус президента $є$ природним або, з іншого боку, об'єктивним явищем, зумовленим складністю політичних обставин, за яких, за звичаєм, і здійснюється керівництво країною іï лідерами $[8,40]$. Визнаною позицією американської політичної думки є й визнання традиційної приналежності осіб, які посідають президентську посаду, до соціально і фінансово обмеженої еліти суспільства [6, 292-296]. I водночас діяльність президентів не розглядається як безпосередній інструмент еліти: «Їхні особисті переваги, їхнє прагнення суспільної підтримки та виборчих голосів, їхнє занепокоєння відносно вердикту історії- все це спрямовує їх на цілі, що виходять за межі інтересів вузької еліти», - зазначає, наприклад, відомий дослідник президенціоналізму США Б. Мірофф [6, 296].

Так, в полі зору дослідників і реальні механізми впливу на позиції глави держави, що, попри зв'язки американських президентів з вузьким колом фінансової або соціально обмеженої еліти, здатні спрямовувати діяльність президентів у напрямі загальнонаціональних інтересів. Мова йде про функціональні повноваження конгресу як законодавчого і водночас представницького органу США; впливи мас-медіа, громадянського суспільства; статусність судової системи, що за умов реальності системи стримування й противаг в американському політич- 
ному процесі - забезпечують врахування на вищому державному (президентському) рівні загальнонаціональних інтересів.

Дослідники, зокрема, визнають відчутне зростання ролі конгресу на противагу президентській адміністрації за постбіполярні часи - чинник, що знайшов підтвердження на прикладах реалізації усіх найбільш конституційно закріплених функцій конгресу - від прийняття законів, визначення асигнувань, підтвердження призначень, ратифікації договорів до здійснення інституційного контролю з нагляду за виконавчою владою в тій сфері діяльності уряду, яка стосується внутрішньої і зовнішньої політики країни. Паралельно з цим помітно зросли представницькі функції конгресу з активізацією механізмів взаємовпливів конгресу і громадськості - від соціальних до індивідуалістичних та інституційних [2; 3; 7].

Особливої ваги, зокрема, в аспекті соціальних чинників набуває громадська думка, що розглядається в американській політичній літературі в ролі одного 3 найдієвіших механізмів впливу на конгрес та, в свою чергу, президента, діючи у вимірі найбільш гострих викликів та роздратувань з боку суспільства. Зазначене зумовлюється традиційним сприйняттям американцями громадської думки нормою представництва в демократичному суспільстві, коли громадськість має відігравати роль «керівника» щодо «агентів»-конгресменів, місією яких є захист інтересів керівника на державному рівні; а також особистою зацікавленістю членів конгресу здобути через захист позицій громадськості підтримку суспільства 3 метою бути переобраними на свої посади на черговий строк.

Такі підходи утворюють чітку схему впливу громадської думки на конгрес, коли незадоволення мас політикою чи поведінкою президента - на прикладі, зокрема, протестного сприйняття в широких американських колах результатів президентських виборів 2016 р.; міграційної політики (заборони в'їзду в країну громадянам декількох переважно мусульманських країн) [19] чи соціальної політики (спроб відміни програми обов'язкового медичного страхування Obamacare) [15] Трампа - сформувало відповідну (принаймні, з боку конгресменів-демократів) протидію виконавчій владі чи їі главі з боку законодавчої влади.

Дієвість громадської думки в системі впливів на конгрес може доповнюватись при цьому іншими соціальними, а також індивідуалістичними та інституційними чинниками, представленими групами інтересу (тиску), впливами індивідуальних осіб, формальних і неформальних об'єднань в конгресі.

Хоча в американській політичній науці усталеною $є$ точка зору про переважання в конгресі груп інтересу, що представляють великий бізнес, підвищений плив на законодавчий процес за постбіполярний період почали набувати групи на підтримку демократії за кордоном, правозахисні групи, національно орієнтовані групи, спрямування яких відбивало тенденції світового розвитку та систему 
національних інтересів США за найновітніші часи. Показовим в цьому плані може бути скорегований в конгресі США курс щодо України і РФ, коли на тлі російської агресії підтримка України прихильниками демократії почала превалювати над інтересами бізнесових кіл, зацікавлених у розвиткові економічних відносин з Росією. Українською тематикою, зокрема, опікувалися Гельсинська комісія та Українська група («кокус») палати представників, а від 2015 р. Український кокус у сенаті, що піднімали питання військової та безпекової підтримки України. Питаннями України серйозно займалася водночас більша частина підрозділів конгресу, включно з підкомітетами комітету з асигнувань палати представників і сенату; комітетом з питань міжнародних відносин сенату та комітетом з питань закордонних справ палати представників США [11].

Неабияке значення щодо курсу на підтримку України відіграли й виступи окремих видатних осіб конгресу США, серед яких на особливу роль заслуговує Дж. Маккейн (1936-2018) - один з найавторитетніших й досвідченіших республіканців, що залишався від початку агресії РФ послідовним захисником інтересів України. У січні 2017 р., разом із Б. Кардіном, Б. Менендесом і ще з сімома сенаторами від обох основних партій він вніс законопроект про введення проти Росії всеосяжних санкцій у зв'язку зі спробами впливу на вибори 2016 р. Законопроект був схвалений Сенатом у червні 2017 р. [12].

Так, саме позиція конгресу щодо України мала особливий вплив на відповідні підходи щодо цього двох останніх американських президентів, причому саме конгрес, як можна припустити, забезпечив характерними для нього методами впливу загалом жорстку позицію щодо РФ Трампа-президента, всупереч неоднозначним заявам щодо Росії Трампа-кандидата в президенти. Адміністрація Трампа фактично виявилася серед найбільш проукраїнських у сучасній істоpiї США: Трамп не тільки продовжив політику дипломатичної, військово-технічної допомоги Україні, а й підтримав сформоване в межах конгресу рішення надання Києву оборонного озброєння; узгодив збільшення фінансової допомоги Україні в 2019 р. до 700 млн дол. США [16].

Особливу роль при цьому щодо налаштованості конгресу впливати певним чином на позицію Трампа-президента відіграв і такий потужний суспільний чинник, як мас-медіа, що виявляють здатність гостро реагувати на резонансні аспекти суспільства (нації), формуючи, таким чином, позицію конгресу як представницького органу влади. Хоча в американській літературі існує точка зору щодо обмеженої можливості критики глави держави через усвідомлення опозицією іiі деструктивності у вимірі іміджу американського керівництва $[4,22]$, приклад 3 адміністрацією Трампа піддає сумніву такий підхід. Так, показовим є надзвичайно критичне і прискіпливе ставлення ЗМІ до Трампа-президента - тенденція, 
що була викликана не тільки сумнівністю моральних якостей та суперечливістю поведінки чинного глави держави (особливо на початкових етапах перебування у Білому домі), а й крайнім негативізмом останнього до мас-медіа, що викликало кризовий стан відносин сторін і навіть чергову публічну заяву в серпні 2018 р. низки впливових американських 3МІ, що ставлення президента до засобів масової інформації загрожує «безпеці свободи» як основоположному принципу демократії [1].

Персоніфіковано критичне ставлення ЗМІ до президента-Трампа, що впливає на позицію конгресу, не відбиває, звісно, усіх сторін проблеми, оскільки практика політичного процесу може передбачати не тільки прямі (від мас-медіа до конгресу), а й зворотні (від конгресу до мас-медіа) зв'язки, коли конгрес формує через ЗМІ слушну для нього громадську думку з актуальних проблем. Втім, що є надзвичайно важливим у цьому плані, американські ЗМІ залишаються важливим регулятором політичних зв'язків між суспільством і державними структурами (конгресом), виступаючи значною мірою самостійною силою щодо офіційних впливів. Показовим, наприклад, $є$ той чинник, що, ініціювавши свого часу розслідування щодо зв'язків штабу Трампа з Москвою в період передвиборчої кампанії 2016 р., представники журналістської спільноти продовжили це розслідування навіть після невизнання таких зв'язків в оприлюдненій доповіді комітету з розвідки палати представників конгресу США та певного контролю щодо подібних публікацій з боку медіагігантів [14].

Варто визнати також, що самостійним регулятором відносин між суспільством і державними структурами - конгресом і президентською адміністрацією, як і системою підтримки легітимності (конституційності) політичної системи, виступає й Верховний суд або, у більш широкому вимірі, судова система США. I хоча звернення до судової структури як механізму захисту інтересів суспільства або його частини на противагу президенту не $\epsilon$ перманентним процесом, суперечливість рішень глави держави не виключає такого розвитку подій. На підтвердження - звернення в лютому 2019 р. до суду 16 штатів США щодо рішення Д. Трампа про оголошення надзвичайного стану з метою залучення останнім (в обхід конгресу) коштів на прикордонну стіну з Мексикою як додаткового правового інструменту захисту позиції громади (громадян) за умов конфліктності інтересів по лінії громадяни - суспільство - президент [17].

Політичне лідерство на прикладі президенціоналізму США $\epsilon$, таким чином, феноменом, що реалізує себе як через безпосередню діяльність осіб, обраних на президентську посаду, так і з урахуванням демократичних засад функціонування суспільства - чіткого розподілу повноважень влади та системи стримування $\mathrm{i}$ противаг в межах політичного процесу; механізмів взаємозв'язку суспільства i 
органів влади; здатності громадян впливати на процес формування політики. Президенціоналізм США доводить тісний взаємозв'язок між політичним лідерством і демократичними засадами розвитку суспільства. Хоча історія США подарувала американській нації чимало видатних лідерів, які своєю діяльністю сприяли розвитку суспільства та ствердженню демократії, саме демократичні засади визначали подальший прогрес США, окреслюючи політику лідерів відповідно до позицій громадян. Аксіомою для нових демократій в цьому плані має стати усвідомлення, що відповідальне лідерство може реалізовуватись тільки за умов поглиблення демократії як передумови рекрутування політиків гідних рівня не вузького кола олігархів, а суспільства і нації.

Подальші дослідження у зазначеному напрямі можуть передбачати відокремлений аналіз механізмів впливу суспільства на реалізацію влади як чинників, що формують сталі політичні зв’ язки по лінії громадяни - влада та визначають основоположні принципи американської демократії .

\begin{abstract}
Theoretical and practical dimensions of political power realization following the example of the US presidentionalism are discussed. The idea of the discourse is what conditions US presidents orientations at nationwide interests notwithstanding elitist status of persons to held presidential posts. In the spotlight - traditionally high demands of American civilians towards moral and professional qualities of the president, ability of elected leader to reply requests and needs of society. Institutional foundations are also of special role regarding nationwide positions of authorities, and first of all - supervision and control over the activity of president and presidential administration from the US Congress, which - by the example of activity of the presented in the Congress interests (pressure) groups, formal and informal association, statements of influential political individuals - reveals its ability to function as counter actor to Executive, realizing thus practical impact of the principle of check and balances. There are also a series of social factors among the mechanisms of impacts upon the presidents with special role within them of mass-media and civil thought. It is proved in the article that notwithstanding ability to influence molding of the social thought in the necessary for the executive power dimension, it (social thought) becomes (under effectiveness of such institutional factor as Congress) a representative of the interests, positions, requests of civilians. Mass-media has also acquired significant role in this respect. While staying mainly as autonomous force upon official authorities, mass-media remains to be regulator of political ties between society and governmental structures. The same role is inherent for the USA judiciary system as additional legal instrument for the support of democracy and protection of the positions of civilians under conflict character of relationship along the line civilians - society - Congress - President.

It is proved in the article that realization of power in order of society supposes as special personal features of the nominees for high level officials posts, but also existence of a stable democratic norms which regulate activity of a leader of nation in dimension of interests and needs of civilians.
\end{abstract}

Key words: power, US presidentionalism, theory, practice, national interests. 


\section{ДЖЕРЕЛА ТА ЛІТЕРАТУРА}

1. A Boston Globe editorial: Jounalists are not the enemy. URL: https://www.bostonglobe.com/opinion/editorials/2018/08/15/editorial/Kt0NFFonrxqBI6NqqennvL/story.html (дата звернення: 15.08.2018).

2. Binder S. A. Acquired Procedural Tendencies and Congressional Reform. S. A. Binder, St. S. Smith. Remaking Congress: Change and Stability in the 1990-s. Washington, D. C., 1995. P. 53-72.

3. Carter R. G. Congress and Post-Cold War U.S. Foreign Policy. After the End. Making U.S. Foreign Policy in Post Cold War World/ ed by James M. Scott. Durham, London: Duke University Press. 1998. P. 108-136.

4. Crabb C. V. Jr., Holt P. M. Invitation to Struggle. Congress, the President, and Foreign Policy. Fourth Edition. Washington: CQ Press. 1992. 322 p.

5. Donald J. Trump. Inaugural address. Friday, January 20, 2017. URL: https:// www.whitehouse.gov/briefings-statements/the-inaugural-address/ (дата звернення: 12.03.2019).

6. Miroff B. The Presidency and Elite Democracy. Debating Democracy. A Reader in American Politics / ed by B. Miroff, R. Seidelman, \& T. Swanstrom Boston, New York: Houghton Mifflin. 1999. P. 281-283; 290-298.

7. Foster D. An «Invitation to Struggle?» The Use of Force Against «Legislatively Vulnerable» American Presidents. International Studies Quarterly. 2006. Vol. 50, № 2. P. 421-444.

8. Rosati J. The Presidency and U.S. Foreign Policy after the Cold War /ed by James M. Scott After the End. Making U.S. Foreign Policy in the Post-Cold War World. Durham and London, 1998. P. 29-56.

9. Американський президенціоналізм. Інститут глави держави в США в персоналіях від зародження до сьогодення / О. В. Бабкіна та ін.: за наук. ред. Н. М. Хоми. Львів: Новий Світ, 2018. 368 с.

10. Вибори президента США: як сталося неймовірне, і чого очікувати Україні? URL: https://dt.ua/internal/vibori-prezidenta-ssha-yak-stalosya-neymovirne-i-chogo-ochikuvati-ukrayini-_.html (дата звернення: 07.03.2019).

11. Дейчаківський О. 100 років підтримки свободи. Конгрес США та Україна. URL: http://www.istpravda.com.ua/articles/2018/09/14/152926/ (дата звернення: 14.09.2018).

12. Джон Маккейн: кандидат у президенти CША, який вболівав за Україну. URL: https://www.bbc.com/ukrainian/features-45143221 (дата звернення: 26.08.2018).

13. Дудко І. Трамп, Дональд Джон. Американський президенщіоналізм. Інститут глави держави в США в персоналіях від зародження до сьогодення. Львів, 2018. С. 357-364. 
14. Помилки медіагігантів. Чому CNN видалив скандальне розслідування про Трампа й Росію URL: https://ms.detector.media/print/ 1411980895/pomilki_ mediagigantiv_chomu_cnn_vidaliv_skandalne_rozsliduvannya_pro_trampa_y_ rosiyu/ (дата звернення: 20.07.2017).

15. Сенат США проголосував за початок скасування Obamacare. URL: https:// www.bbc.com/ukrainian/news-38593360 (дата звернення: 12.01.2017).

16. Трамп підписав бюджет США, що збільшує допомогу Україні. URL: https://www.radiosvoboda.org/a/news-us-trump-signs-budget/29773658. html (дата звернення: 16.02.2019).

17. Трамп проти штатів. 16 штатів США подали в суд на Трампа через надзвичайний стан. News/ Україна. URL: https://www.bbc.com/ukrainian/features47288717 (дата звернення: 19.02.2019).

18. Трамп отримав найнижчий рівень довіри американців порівняно з Обамою, Клінтоном та Бушем. Інфографіка. URL: https://tsn.ua/politika/reyting-trampapered-promizhnimi-viborami-do-kongresu-ye-menshim-nizh-u-troh-yogo-poperednikiv-1225002.html (дата звернення: 28.09.2018).

19. У США пройшли протести проти міграційної політики Трампа. URL: https://ukr.segodnya.ua/world/usa/v-ssha-proshli-protesty-protiv-migracionnoypolitiki-trampa-1150864.html (дата звернення: 29.06.2018).

\section{References}

1. A Boston Globe editorial: Jounalists are not the enemy. URL: https:// www.bostonglobe.com/opinion/editorials/2018/08/15/editorial/Kt0NFFon rxqBI6NqqennvL/story.html (data zvernennya: 15.08.2018)

2. Binder, S. A. (1995). Acquired Procedural Tendencies and Congressional Reform. In S. A. Binder, \& St. S. Smith (Eds.), Remaking Congress: Change and Stability in the 1990-s (pp. 53-72). Washington, D. C.

3. Carter, R. G. (1998). Congress and Post-Cold War U.S. Foreign Policy. In James M. Scott $(E d$.$) . After the End. Making U.S. Foreign Policy in Post Cold War$ World (pp. 108-136). Durham, London: Duke University Press.

4. Crabb, C. V. Jr., \& Holt, P. M. (1992). Invitation to Struggle. Congress, the President, and Foreign Policy. Fourth Edition. Washington: CQ Press.

5. Donald, J. Trump. Inaugural address. Friday, January 20, 2017. URL: https:// www.whitehouse.gov/briefings-statements/the-inaugural-address/ (data zvernennya: 12.03.2019).

6. Miroff, B. (1999). The Presidency and Elite Democracy. In B. Miroff, R. Seidelman, \& T. Swanstrom (Eds.), Debating Democracy. A Reader in American Politics (pp. 281-283; 290-298). Boston, New York: Houghton Mifflin. 
7. Rosati, J. (1998). The Presidency and U.S. Foreign Policy after the Cold War / In James M. Scott $(E d$.). After the End. Making U.S. Foreign Policy in the Post-Cold War World (pp. 29-56). Durham and London.

8. Tierney, J. T. (1994). Congressional Activism in Foreign Policy: Its Varied Forms and Stimuli. In D. A. Deese (Ed.), The New Politics of American Foreign Policy (pp. 102-129). New York: Cengage Learning.

9. Khoma, N. M. (Ed.). (2018). Amerykanskyi prezidentsionalizm. Instytut glavy derzhavy v SSHA v personaliiakh vid zarodzhennia do siohodennia [American presidentionalism. Institute of the US head of state in personalities from the origin till today]. Lviv: Svit.

10. Vybory prezydenta SSHA: Yak stalosia neimovirne i choho ochikuvaty Ukraini? [Elections of the US president: How incredible has taken place and what Ukraine can await?]. URL: https://dt.ua/internal/vibori-prezidenta-ssha-yak-stalosya-neymovirne-i-chogo-ochikuvati-ukrayini-_.html (data zvernennya: 07.03.2019).

11. Deichakivskyi, O. 100 rokiv pidtrymky cvobody. Konhress SSHA ta Ukraina [100 years of supporting freedom. The US Congress and Ukraine]. URL: http://www.istpravda.com.ua/articles/2018/09/14/152926/) (data zvernennya: 14.09.2018).

12. Dzhon Makkein: kandydat u prezydenty SSHA, yakyi vbolivav za Ukrainu [John McCain: US presidential candidate, who cheered for Ukraine]. URL: https://www.bbc.com/ukrainian/features-45143221 (in Ukr.) (data zvernennya: 26.08.2018).

13. Dudko, I. (2018). Tramp, Donald Dzhon [Trump, Donald John]. In N. M. Khoma (Ed.), American presidentionalism. Institute of the US head of state in personalities from the origin till today (357-364). Lviv: Svit.

14. Pomylky mediahihantiv. Chomu CNN vydalyv skandalne rozsliduvannia pro Trampa I Rossiiu [Mistakes of media-magnates. Why did CNN delete scandal investigations about Trump and Russia]. URL: https://ms.detector.media/print/ 1411980895/pomilki_mediagigantiv_chomu_cnn_vidaliv_skandalne_rozsliduvannya_pro_trampa_y_rosiyu/ (дата звернення: 20.07.2017 ).

15. Senat SSHA proholosuvav za pochatok skasuvannia Obamacare [The US Senate voted for the beginning Obamacare canceling]. URL: https://www.bbc.com/ ukrainian/news-38593360 (дата звернення: 12.01.2017).

16. Tramp pidpysav biudzhet, shcho zbilshue dopomohu Ukraini [Trump signed the US budget which enlarges aid for Ukraine]. URL: https://www.radiosvoboda. org/a/news-us-trump-signs-budget/29773 658. html. (дата звернення: 16.02.2019).

17. Tramp proty shtativ. 16 shtativ SSHA podaly v sud na Trampa cherez nadzvychainyi stan [Trump vs states. 16 USA states sued Trump upon emergency]. 
News/Ukraine. URL: https://www.bbc.com/ukrainian/features-47288717 (дата звернення: 19.02.2019).

18. Tramp otrymav nainyzhchyi riven doviry amerukantsiv porivniano z Obamoiu, Klinton ta Bushem [Trump gained the lowest level of trust from Americans comparing Obama, Clinton and Bush. Infographics]. URL: https://tsn.ua/politika/ reyting-trampa-pered-promizhnimi-viborami-do-kongresu-ye-menshim-nizh-utroh-yogo-poperednikiv-1225002.html (дата звернення: 28.09.2018).

19. U SSHA proishly protesty proty mihratsiinoi polityky Trampa [Protests against migratory policy of Trump took place in the USA]. URL: https://ukr.segodnya.ua/world/usa/v-ssha-proshli-protesty-protiv-migracionnoy-politiki-trampa1150864.html. (дата звернення: 29.06.2018). 